\title{
Pendugaan Komponen Ragam dan Nilai Heritabilitas pada Dua Populasi Cabai Rawit Merah (Capsicum frutescens L.)
}

\author{
The Estimation of Varian Components and Heritability Two Population of Bird \\ Pepper (Capsicum frutescens L.)
}

\author{
Abdul Hakim¹, Muhamad Syukur ${ }^{2 *}$, dan Yudiwanti Wahyu ${ }^{2}$ \\ Diterima 26 Oktober 2018/Disetujui 04 Februari 2019
}

\begin{abstract}
Assembling plant variety requires genetic information about the concerned traits. One way to obtain genetic information is through estimating genetic component and heritability. This experiment aims to obtain information varians component variety and heritability in 2 populations of bird pepper. Each population $P 1, P 2$, and $F 1$ was planted with 40 plants, BCP1 and BCP 2 was planted with 100 plants and F2 was planted with 300 plants. Results in IPB C285 x IPB C290 population show the heritability broad sense with height category for all characters except fruit diameter. The number fruits per plant and fruit thickness has the highest category for heritability narrow sense. Results in IPB C321 x IPB C290 population heretability broad sense with hight category for all characters except weight per fruit. Fruit length was included in the high category for narrow sense heritability. The ratio of additive varians was greater than non additive varians in IPB C285 x IPB C290 population for number fruit per plant, weight per fruit, fruit length, fruit diameter, fruit thickness and harvest time while in IPB C321 x IPB C290 population number fruit per plant, fruit length, fruit thickness and fruit diameter. The selection method that can be used in both populations was the pedigree method so that selection activities can be carried out in early generation. The population IPB C285 x IPB C290 pedigree selection method was carried out on number fruits per plant and weight per fruit whereas in IPB C321 x IPB C290 population, pedigree selection method was carried out on fruit length.
\end{abstract}

Keywords: additive, bird pepper, character, diversity, genetic, heritability,

\begin{abstract}
ABSTRAK
Perakitan suatu varietas tanaman memerlukan informasi genetik mengenai sifat yang diinginkan. Salah satu cara untuk memperoleh informasi genetik yaitu melalui pendugaan komponen genetik dan nilai heritabilitas. Percobaan ini yang bertujuan memperoleh informasi komponen ragam dan nilai heritabilitasnya pada 2 populasi tanaman cabai rawit. Masing-masing populasi P1, P2, dan F1 ditanam dengan jumlah 40 tanaman, BCP1 dan BCP 2 sebanyak 100 tanaman dan F2 sebanyak 300 tanaman. Hasil pada populasi IPB C285 x IPB C290 menunjukkan nilai heritabilitas arti luas kategori tinggi untuk semua karakter kecuali pada karakter diameter buah. Jumlah buah per tanaman dan tebal daging buah memiliki nilai heritabilitas arti sempit kategori tinggi. Hasil pada populasi IPB C321 x IPB C290 menunjukkan heritabilitas arti luas kategori tinggi untuk semua karakter kecuali karakter bobot per buah. Karakter panjang buah termasuk dalam kategori tinggi untuk heritabilitas arti sempit. Rasio ragam aditif lebih besar daripada ragam non aditif pada populasi IPB C285 x IPB C290 untuk karakter jumlah buah per tanaman, bobot per buah, panjang buah, diameter buah, tebal daging buah dan umur panen sedangkan pada populasi IPB C321 x IPB C290 yaitu karakter jumlah buah per tanaman, panjang buah, tebal daging buah dan diameter buah. Metode seleksi yang bisa digunakan pada kedua populasi ini yaitu metode pedigree sehingga kegiatan seleksi bisa dilakukan pada generasi awal. Populasi IPB C285 x IPB C290 metode seleksi pedigree dilakukan pada karakter jumlah buah
\end{abstract}

\footnotetext{
${ }^{1}$ Mahasiswa Pascasarjana, Program Studi Pemuliaan dan Bioteknologi Tanaman,

Sekolah Pascasarjana, Institut Pertanian Bogor

${ }^{2}$ Departemen Agronomi dan Hortikultura, Fakultas Pertanian, Institut Pertanian Bogor

Jl. Meranti, Kampus IPB Darmaga, Bogor 16680

E-mail : muhsyukur@ipb.ac.id (*Penulis korespondensi)
} 
per tanaman dan bobot per buah sedangkan pada populasi IPB C321 x C290 metode seleksi pedigree dilakukan pada karakter panjang buah

Kata kunci: aditif, cabai rawit, genetik, heritabilitas, karakter, keragaman

\section{PENDAHULUAN}

Cabai rawit merah (Capsicum frutescens L.) adalah salah satu komoditas unggulan hortikultura di Indonesia dan merupakan salah satu jenis sayuran yang sangat berpotensi untuk dikembangkan. Cabai rawit merah banyak digunakan sebagai bahan campuran untuk mendapatkan rasa pedas. Industri pembuatan saus biasanya menggunakan cabai rawit ini sebagai komponen campuran penyumbang rasa pedas.

Di Indonesia, produktivitas cabai rawit merah pada tahun 2016 sekitar 6.69 ton ha $^{-1}$ (BPS dan Dirjen Horti, 2018), padahal potensi cabai rawit merah bisa mencapai 12-20 ton $\mathrm{ha}^{-1}$ (Sujinto dan Dianawati, 2015). Produktivitas cabai rawit merah yang masih rendah ini disebabkan oleh banyak faktor, salah satunya adalah petani belum banyak menggunakan varietas unggul berdaya hasil tinggi. Produktivitas cabai rawit merah masih dapat ditingkatkan salah satunya dengan kegiatan pemuliaan tanaman melalui proses perakitan varietas. Jumlah varietas cabai rawit merah di Indonesia masih tergolong sedikit sekitar 35 varietas (Direktorat Perbenihan Hortikultura, 2018) sehingga perlu dilakukan penelitian untuk merakit varietas cabai rawit merah agar semakin banyak pilihan bagi para petani untuk menanam jenis cabai rawit merah.

Informasi pendugaan parameter genetik sangat diperlukan untuk memperbaiki karakter suatu populasi (Ekowahyuni et al., 2015). Menurut Alia et al. (2004), nilai parameter genetik yang diperlukan dalam proses seleksi terdiri dari aksi gen, variabilitas genetik dan heritabilitas. Heritabilitas merupakan salah satu parameter genetik yang penting dalam kegiatan pemuliaan tanaman. Pendugaan komponen ragam dan nilai heritabilitas sudah banyak dilakukan pada cabai besar (Satriawan et al., 2017), cabai keriting (Yunandra et al., 2017), dan cabai rawit spesies Capsicum annuиm L. (Arif et al., 2014) sedangkan pada cabai rawit merah (Capsicum frutescens $\mathrm{L}$.) belum banyak dilakukan, sehingga dengan adanya penelitian ini diharapkan dapat menambah informasi terkait pendugaan komponen ragam dan heritabilitas, khususnya pada cabai rawit Capsicum frutescens $\mathrm{L}$.

Adanya karakter yang memiliki nilai heritabilitas tinggi akan memudahkan perbaikan karakter melalui seleksi dibandingkan dengan karakter dengan nilai heritabilitas rendah. Nilai heritabilitas menggambarkan besar ragam genotipe yang masih dapat terus diwariskan pada keturunan berikutnya. Percobaan ini bertujuan menduga komponen ragam dan nilai heritabilitas karakter komponen hasil pada dua populasi cabai rawit merah (Capsicum frutescens L.).

\section{BAHAN DAN METODE}

Penelitian ini dilakukan dari bulan Januari sampai Juni 2016. Pembentukan populasi dilakukan di Kebun Percobaan Leuwikopo IPB dan Kebun Perumahan IPB Alam Sinar. Bahan tanaman yang digunakan adalah 2 populasi cabai rawit yaitu populasi IPB C285 x IPB C290 dan IPB C321 x IPB C290. Genotipe IPB C285 merupakan hasil selfing dari varietas komersial nasional yang mempunyai keunggulan jumlah buah yang banyak, namun adaptasi di lahan kurang baik. Genotipe IPB C290 merupakan hasil selfing dari varietas lokal yang mempunyai keunggulan ukuran buah yang besar dan memiliki daya adaptasi yang baik. Genotipe IPB C321 merupakan hasil selfing dari varietas introduksi yang mempunyai keunggulan jumlah buah yang banyak, tingkat kepedasan yang tinggi dan adaptasi kurang baik. Masingmasing kombinasi persilangan terdiri atas populasi tetua $1(\mathrm{P} 1)$, tetua $2(\mathrm{P} 2)$, turunan pertama (F1), masing-masing ditanam sebanyak 40 tanaman, backcross ke tetua betina (BCP1), backcross ke tetua jantan (BCP2) masing-masing ditanam sebanyak 100 tanaman, dan turunan kedua (F2) sebanyak 300 tanaman. Pembentukan populasi dilakukan dengan melakukan persilangan buatan dan selfing. Populasi yang dibentuk dengan persilangan buatan adalah $\mathrm{F} 1, \mathrm{BCP} 1$, dan 
BCP2, sedangkan populasi $\mathrm{P} 1, \mathrm{P} 2, \mathrm{~F} 2$ diperoleh dari selfing.

Penyemaian dilaksanakan di Laboratorium Bagian Genetika dan Pemuliaan Tanaman Departemen Agronomi dan Hortikultura IPB. Penanaman di lapangan dilaksanakan di Kebun Percobaan Leuwikopo IPB. Karakter yang diamati adalah karakter komponen hasil, yaitu: umur berbunga (HST), umur panen (HST), bobot per buah $(\mathrm{g})$, diameter buah $(\mathrm{mm})$, tebal daging buah $(\mathrm{mm})$, panjang buah $(\mathrm{cm})$, jumlah buah per tanaman (buah), dan bobot buah per tanaman (g). Analisis data mengacu pada Arif et al. (2012), yaitu: 1) penghitungan komponen ragam yang dihitung yang terdiri atas ragam fenotipe : $\mathrm{VP}=\mathrm{V}_{\mathrm{F} 2}$; ragam lingkungan $: \mathrm{VE}=$ $\left(\mathrm{V}_{\mathrm{P} 1}+\mathrm{V}_{\mathrm{P} 2}+\mathrm{V}_{\mathrm{F} 1}\right) / 3$; ragam genotipe $: \mathrm{VG}=\mathrm{VP}$ - VE; ragam silang balik : $\mathrm{V}_{\mathrm{BCP} 1}$ dan $\mathrm{V}_{\mathrm{BCP} 2}$; ragam aditif $\left(\mathrm{V}_{\mathrm{A}}\right): \mathrm{V}_{\mathrm{A}}=2 \mathrm{~F} 2-\left(\mathrm{V}_{\mathrm{BCP} 1}+\mathrm{V}_{\mathrm{BCP} 2}\right)$; 2) Pendugaan nilai heritabilitas terdiri atas nilai heritabilitas arti luas dan heritabilitas arti sempit mengacu pada Syukur et al. (2015).

$$
\begin{aligned}
h^{2}{ }_{b s} & =\frac{V_{F 2}-\left[\frac{V_{F 1}+V_{P 1}+V_{P 2}}{3}\right]}{V_{F 2}} ; \\
h^{2}{ }_{n s} & =\frac{2 V_{F 2}-\left(V_{B C P 1}+V_{B C P 2}\right)}{V_{F 2}}
\end{aligned}
$$

Keterangan:

$h_{b s}^{2} \quad$ : heritabilitas arti luas,

$\mathrm{V}_{\mathrm{F} 1} \quad$ : ragam populasi $\mathrm{F} 1$,

$h_{n s}^{2} \quad$ : heritabilitas arti sempit,

$\mathrm{V}_{\mathrm{F} 2} \quad$ : ragam populasi $\mathrm{F}$ 2,

$\mathrm{V}_{\mathrm{BCP} 1}$ : ragam populasi silang balik ke $\mathrm{P} 1$,

$\mathrm{V}_{\mathrm{P} 1} \quad$ : ragam populasi $\mathrm{P} 1$,

$\mathrm{V}_{\mathrm{BCP2}}$ : ragam populasi silang balik ke $\mathrm{P} 2$,

$\mathrm{V}_{\mathrm{P} 2} \quad$ : ragam populasi $\mathrm{P} 2$.

kategori heritabilitas $h_{b s}^{2}$ dan $h_{n s}^{2}$ : tinggi $h_{b s}^{2} \&$ $h^{2}{ }_{n s} \geq 50 \%$; sedang $20 \geq h_{b s}^{2} \& h_{n s}^{2} \geq 50 \%$; rendah $h_{b s}^{2} \& h_{n s}^{2} \leq 20 \%$.

Nilai rasio ragam aditif/non aditif $=$ Ragam aditif/ragam non aditif. Jika nilai rasio diatas 1 maka dikendalikan aksi gen aditif, jika nilai rasio $<0$, maka dikendalikan aksi gen non aditif.

\section{HASIL DAN PEMBAHASAN}

Tabel 1 merupakan nilai tengah, ragam dan selang untuk karakter bobot buah per tanaman, jumlah buah per tanaman, umur berbunga dan umur panen pada populasi IPB C285 x IPB C290. Keragaman paling besar untuk semua karakter terdapat pada populasi F2 hal ini dikarenakan pada populasi F2 merupakan populasi yang bersegregasi paling maksimal. Keragaman terbesar setelah populasi F2 yaitu pada populasi BCP1 dan BCP2. Populasi P1 dan P2 memiliki keragaman relatif lebih kecil karena populasi P1 dan P2 adalah populasi yang homogen dan homozigot sehingga keragaman yang terjadi karena faktor lingkungan. Populasi F1 juga mempunyai keragaman yang kecil juga karena pada populasi memiliki keseragaman karena merupakan populasi homogen heterozigot.

Nilai tengah karakter bobot buah per tanaman F2 lebih besar dibandingkan dengan semua populasi. Nilai tengah karakter jumlah buah per tanaman F2 lebih kecil dari pada tetua P1 dan BCP1. Nilai tengah pada BCP1 menjadi lebih besar karena merupakan persilangan $\mathrm{F} 1$ dengan tetua P1 yang memiliki jumlah buah per tanaman yang banyak sehingga nilai tengah BCP1 menjadi lebih tinggi karena semakin banyaknya gen-gen yang mengendalikan jumlah buah yang terakumulasi pada populasi BCP1. Nilai tengah umur berbunga dan umur panen pada populasi F2 lebih besar dibandingkan dengan populasi yang lain. Selang umur berbunga yaitu 29-49 hari setelah tanam (HST) dan umur panen (69-88 HST) pada populasi $\mathrm{F} 2$ lebih besar dibandingkan dengan populasi yang lain (Tabel 1).

Keragaman terbesar pada populasi F2 hasil persilangan IPB C285 x IPB C290 disusul dengan keragaman pada populasi BCP1 dan $\mathrm{BCP} 2$. Keragaman paling kecil terdapat pada populasi P1, P2, dan F1. Nilai tengah untuk karakter bobot per buah dan panjang buah nilai maksimum terdapat pada populasi BCP2. Hal ini karena populasi BCP2 merupakan hasil persilangan $\mathrm{F} 1$ kepada tetua $\mathrm{P} 2$ sehingga bisa meningkatkan bobot per buah dan panjang per buah. Nilai tengah maksimum diameter buah terdapat pada populasi P2 yaitu sekitar 14.94 $\mathrm{mm}$ sedangkan pada populasi F2 hanya mencapai $14.72 \mathrm{~mm}$. Nilai maksimum untuk karakter tebal daging buah terdapat pada populasi F2 sehingga pada populasi ini terdapat kandidat tanaman yang memiliki tebal daging buah yang bisa dijadikan sebagai calon varietas (Tabel 2). 
Tabel 1. Rekapitulasi nilai tengah, selang, bobot buah per tanaman, jumlah buah, umur berbunga dan umur panen populasi IPB C285 x IPB C290

\begin{tabular}{|c|c|c|c|c|c|}
\hline \multirow{2}{*}{\multicolumn{2}{|c|}{ Populasi }} & \multicolumn{4}{|c|}{ Karakter } \\
\hline & & $\begin{array}{c}\text { BBT } \\
(\mathrm{g})\end{array}$ & $\begin{array}{l}\text { JMB } \\
\text { (buah) }\end{array}$ & $\begin{array}{c}\text { UB } \\
\text { (HST) }\end{array}$ & $\begin{array}{c}\text { UP } \\
\text { (HST) }\end{array}$ \\
\hline \multirow[t]{3}{*}{$\mathrm{P} 1$} & Nilai tengah & 203.72 & 234.25 & 41.00 & 81.75 \\
\hline & Ragam & 3491.85 & 8674.69 & 5.00 & 3.69 \\
\hline & Selang & $141.40-270.61$ & $131.00-349.00$ & $38.00-44.00$ & $79.00-84.00$ \\
\hline \multirow[t]{3}{*}{$\mathrm{P} 2$} & Nilai tengah & 115.48 & 84.82 & 39.36 & 82.36 \\
\hline & Ragam & 4494.40 & 3147.16 & 6.85 & 7.45 \\
\hline & Selang & $45.45-230.80$ & $30.00-213.00$ & $35.00-44.00$ & $77.00-86.00$ \\
\hline \multirow[t]{3}{*}{$\mathrm{F} 1$} & Nilai tengah & 57.51 & 62.20 & 36.50 & 76.70 \\
\hline & Ragam & 569.91 & 605.16 & 5.85 & 8.21 \\
\hline & Selang & $30.14-93.07$ & $26.00-104.00$ & $32.00-41.00$ & $71.00-81.00$ \\
\hline \multirow[t]{3}{*}{$\mathrm{F} 2$} & Nilai tengah & 161.36 & 134.92 & 42.05 & 82.58 \\
\hline & Ragam & 14531.53 & 11974.67 & 23.35 & 15.12 \\
\hline & Selang & $35.41-519.11$ & $23-418$ & $29.00-49.00$ & $69.00-88.00$ \\
\hline \multirow[t]{3}{*}{ BCP1 } & Nilai tengah & 132.70 & 136.11 & 36.67 & 78.11 \\
\hline & Ragam & 10203.61 & 11177.65 & 20.67 & 14.77 \\
\hline & Selang & $47.24-362.15$ & $56.00-377.00$ & $26.00-41.00$ & $69.00-82.00$ \\
\hline \multirow[t]{3}{*}{$\mathrm{BCP} 2$} & Nilai tengah & 158.67 & 107.47 & 38.93 & 81.00 \\
\hline & Ragam & 14347.04 & 6119.18 & 15.13 & 10.40 \\
\hline & Selang & $62.37-517.79$ & $40.00-307.00$ & $32.00-45.00$ & $74.00-87.00$ \\
\hline
\end{tabular}

Tabel 2. Rekapitulasi nilai tengah, selang, bobot per buah, panjang buah, diameter buah, dan tebal daging buah, populasi IPB C285 x IPB C290

\begin{tabular}{|c|c|c|c|c|c|}
\hline \multirow{2}{*}{\multicolumn{2}{|c|}{ Populasi }} & \multicolumn{4}{|c|}{ Karakter } \\
\hline & & $\begin{array}{l}\text { BB } \\
(\mathrm{g})\end{array}$ & $\begin{array}{l}\mathrm{PB} \\
(\mathrm{cm})\end{array}$ & $\begin{array}{l}\mathrm{DB} \\
(\mathrm{mm})\end{array}$ & $\begin{array}{l}\text { TDB } \\
(\mathrm{mm})\end{array}$ \\
\hline \multirow[t]{3}{*}{ P1 } & Nilai tengah & 1.20 & 3.65 & 10.26 & 0.97 \\
\hline & Ragam & 0.07 & 0.05 & 0.68 & 0.01 \\
\hline & Selang & $0.99-1.65$ & $3.32-3.92$ & $9.61-11.63$ & $0.81-1.15$ \\
\hline \multirow[t]{3}{*}{$\mathrm{P} 2$} & Nilai tengah & 2.36 & 4.39 & 13.53 & 1.55 \\
\hline & Ragam & 0.07 & 0.10 & 0.74 & 0.02 \\
\hline & Selang & $2.09-2.76$ & $3.94-4.94$ & $12.42-14.94$ & $1.31-1.80$ \\
\hline \multirow[t]{3}{*}{$\mathrm{F} 1$} & Nilai tengah & 1.74 & 4.38 & 11.75 & 1.24 \\
\hline & Ragam & 0.08 & 0.04 & 1.09 & 0.04 \\
\hline & Selang & $1.42-2.45$ & $4.10-4.86$ & $10.30-14.51$ & $0.97-1.64$ \\
\hline \multirow[t]{3}{*}{$\mathrm{F} 2$} & Nilai tengah & 1.86 & 4.22 & 12.02 & 1.37 \\
\hline & Ragam & 0.16 & 0.18 & 1.33 & 0.07 \\
\hline & Selang & $1.18-2.49$ & $3.16-4.96$ & $10.01-14.72$ & $0.81-1.88$ \\
\hline \multirow[t]{3}{*}{ BCP1 } & Nilai tengah & 1.62 & 3.98 & 10.89 & 1.38 \\
\hline & Ragam & 0.15 & 0.16 & 0.89 & 0.05 \\
\hline & Selang & $1.07-2.43$ & $3.28-4.42$ & $9.51-12.28$ & $1.00-1.81$ \\
\hline \multirow[t]{3}{*}{ BCP2 } & Nilai tengah & 2.09 & 4.57 & 12.75 & 1.50 \\
\hline & Ragam & 0.10 & 0.15 & 1.30 & 0.05 \\
\hline & Selang & $1.53-2.79$ & $4.12-5.68$ & $11.20-14.45$ & $1.13-1.87$ \\
\hline
\end{tabular}

Keterangan: BB: bobot per buah; PB: panjang buah; DB: diameter buah; TDB: tebal daging buah.

Keragaman terbesar pada populasi F2 hasil persilangan IPB C285 x IPB C290 disusul dengan keragaman pada populasi BCP1 dan
BCP2. Keragaman paling kecil terdapat pada populasi P1, P2, dan F1. Nilai tengah untuk karakter bobot per buah dan panjang buah nilai 
maksimum terdapat pada populasi $\mathrm{BCP} 2$. Hal ini karena populasi $\mathrm{BCP} 2$ merupakan hasil persilangan F1 kepada tetua P2 sehingga bisa meningkatkan bobot per buah dan panjang per buah. Nilai tengah maksimum diameter buah terdapat pada populasi P2 yaitu sekitar 14.94 $\mathrm{mm}$ sedangkan pada populasi $\mathrm{F} 2$ hanya mencapai $14.72 \mathrm{~mm}$. Nilai maksimum untuk karakter tebal daging buah terdapat pada populasi F2 sehingga pada populasi ini terdapat kandidat tanaman yang memiliki tebal daging buah yang bisa dijadikan sebagai calon varietas (Tabel 2).

Keragaman paling besar untuk semua karakter terdapat pada populasi F2 hal ini dikarenakan pada populasi F2 merupakan populasi yang bersegregasi maksimal. Keragaman terbesar setelah populasi F2 adalah populasi BCP1 dan BCP2. Keragaman yang paling kecil terdapat pada populasi P1, P2 dan F1. Nilai tengah dan nilai maksimum karakter bobot buah per tanaman terdapat pada populasi BCP2 karena pada populasi ini terakumulasi gen-gen yang berasal dari P2 sehingga menjadikan bobot buah per tanamannya menjadi lebih besar. Nilai tengah dan nilai maksimun pada populasi F2 lebih besar dibandingkan dengan populasi lainnya. Hal ini menunjukkan bahwa pada populasi F2 terdapat kandidat tanaman yang memiliki jumlah buah lebih besar dari pada kedua tetuanya. Nilai tengah dan selang untuk karakter umur berbunga dan umur panen pada populasi F2 nilainya lebih kecil daripada populasi lain. Berbeda dengan karakterkarakter yang lain, untuk kedua karakter ini biasanya dipilih tanaman yang memiliki umur berbunga dan umur panen yang lebih pendek sehingga tanaman bisa cepat dipanen (Tabel 3).

Tabel 4 merupakan rekapitulasi untuk nilai tengah, ragam, selang untuk karakter bobot per buah, panjang buah, diameter buah, dan tebal daging buah. Keragaman pada masing-masing karakter terdapat pada populasi F2 yang mempunyai keragaman terbesar disusul dengan populasi BCP1 dan BCP2. Keragaman paling kecil terdapat pada populasi P1, P2 dan F1. Nilai maksimum untuk karakter bobot per buah, panjang buah, diameter buah dan tebal daging buah terdapat pada populasi BCP2. Hal ini karena adanya akumulasi gengen yang berasal dari tetua P2 sehingga hasilnya menjadi lebih besar dibandingkan pada populasi F2 dan P2.

Tabel 3. Rekapitulasi nilai tengah, selang, bobot buah per tanaman, jumlah buah, umur berbunga dan umur panen populasi IPB C321 x IPB C290

\begin{tabular}{|c|c|c|c|c|c|}
\hline \multirow{2}{*}{\multicolumn{2}{|c|}{ Populasi }} & \multicolumn{4}{|c|}{ Karakter } \\
\hline & & $\begin{array}{c}\text { BBT } \\
(\mathrm{g})\end{array}$ & $\begin{array}{c}\text { JMB } \\
\text { (buah) }\end{array}$ & $\begin{array}{c}\mathrm{UB} \\
\text { (HST) }\end{array}$ & $\begin{array}{c}\text { UP } \\
\text { (HST) }\end{array}$ \\
\hline \multirow[t]{3}{*}{ P1 } & Nilai tengah & 34.44 & 24.88 & 39.71 & 78.57 \\
\hline & Ragam & 93.96 & 56.62 & 7.24 & 8.29 \\
\hline & Selang & $25.08-50.34$ & $21.00-41.00$ & $37.00-44.00$ & $75.00-83.00$ \\
\hline \multirow{3}{*}{$\mathrm{P} 2$} & Nilai tengah & 115.48 & 84.82 & 39.36 & 82.36 \\
\hline & Ragam & 4494.40 & 3147.16 & 6.85 & 7.45 \\
\hline & Selang & $45.45-230.80$ & $30.00-213.00$ & $35.00-44.00$ & $77.00-86.00$ \\
\hline \multirow[t]{3}{*}{$\mathrm{F} 1$} & Nilai tengah & 131.85 & 124.08 & 32.83 & 77.58 \\
\hline & Ragam & 4484.60 & 3255.36 & 8.15 & 11.17 \\
\hline & Selang & $48.83-257.72$ & $39.00-236.00$ & $25.00-35.00$ & $69.00-81.00$ \\
\hline \multirow[t]{3}{*}{ F2 } & Nilai tengah & 157.96 & 165.83 & 32.33 & 72.90 \\
\hline & Ragam & 9889.39 & 10738.69 & 21.52 & 23.03 \\
\hline & Selang & $43.58-395.19$ & $44.00-455.00$ & $20.00-38.00$ & $65.00-81.00$ \\
\hline \multirow[t]{3}{*}{ BCP1 } & Nilai tengah & 133.37 & 151.90 & 38.24 & 79.10 \\
\hline & Ragam & 7408.15 & 10511.79 & 20.59 & 17.89 \\
\hline & Selang & $54.33-319.70$ & $53.00-409.00$ & $33.00-45.00$ & $69.00-86.00$ \\
\hline \multirow[t]{3}{*}{ ВСР2 } & Nilai tengah & 154.71 & 137.58 & 36.30 & 78.39 \\
\hline & Ragam & 9161.76 & 6075.13 & 17.78 & 22.87 \\
\hline & Selang & $47.74-459.26$ & $40.00-294.00$ & $25.00-42.00$ & $68.00-84.00$ \\
\hline
\end{tabular}

Keterangan: BBT: bobot buah per tanaman; JMB: jumlah buah per tanaman; UB: umur berbunga; UP: umur panen. 
Tabel 4. Rekapitulasi rataan, selang, bobot per buah, panjang buah, diameter buah, tebal daging buah, dan panjang tangkai buah populasi IPB C321 x IPB C290

\begin{tabular}{llrrrr}
\hline & & \multicolumn{4}{c}{ Karakter } \\
\cline { 3 - 6 } & Populasi & \multicolumn{1}{c}{$\begin{array}{c}\text { BB } \\
(\mathrm{g})\end{array}$} & $\begin{array}{c}\text { PB } \\
(\mathrm{cm})\end{array}$ & $\begin{array}{c}\text { DB } \\
(\mathrm{mm})\end{array}$ & $\begin{array}{c}\text { TDB } \\
(\mathrm{mm})\end{array}$ \\
\hline P1 & Nilai tengah & 0.96 & 2.65 & 9.51 & 1.03 \\
& Ragam & 0.03 & 0.01 & 0.50 & 0.01 \\
& Selang & $0.85-1.30$ & $2.48-2.84$ & $8.66-10.53$ & $0.94-1.29$ \\
P2 & Nilai tengah & 2.36 & 4.39 & 13.53 & 1.55 \\
& Ragam & 0.07 & 0.10 & 0.74 & 0.02 \\
& Selang & $2.09-2.76$ & $3.94-4.94$ & $12.42-14.94$ & $1.31-1.80$ \\
F1 & Nilai tengah & 1.95 & 3.88 & 12.90 & 1.44 \\
& Ragam & 0.19 & 0.13 & 1.14 & 0.03 \\
& Selang & $1.26-2.65$ & $3.22-4.32$ & $10.84-14.77$ & $1.21-1.73$ \\
F2 & Nilai tengah & 1.54 & 3.60 & 10.41 & 1.36 \\
& Ragam & 0.16 & 0.34 & 1.59 & 0.04 \\
& Selang & $0.81-2.58$ & $2.82-4.80$ & $7.51-13.61$ & $1.00-1.79$ \\
BCP1 & Nilai tengah & 1.44 & 3.30 & 11.15 & 1.34 \\
& Ragam & 0.13 & 0.26 & 1.25 & 0.03 \\
& Selang & $0.68-2.16$ & $2.56-4.12$ & $9.13-13.05$ & $1.09-1.68$ \\
BCP2 & Nilai tengah & 1.91 & 4.17 & 12.80 & 1.51 \\
& Ragam & 0.16 & 0.21 & 1.52 & 0.04 \\
& Selang & $1.28-2.85$ & $2.68-5.00$ & $10.40-15.81$ & $1.10-1.94$ \\
\hline Keteranyyyy
\end{tabular}

Keterangan: BB: bobot per buah; PB: panjang buah; DB: diameter buah; TDB: tebal daging buah.

Huda et al. (2017) menyatakan bahwa pendugaan komponen ragam digunakan dalam studi genetika untuk sifat kuantitatif. Syukur et al. (2015) menyatakan bahwa heritabilitas merupakan proporsi keragaman yang disebabkan oleh genetik atau rasio ragam genetik terhadap ragam total. Heritabilitas arti luas $\left(h_{b s}^{2}\right)$ merupakan rasio antara ragam genetik total dengan ragam fenotipik. Nilai komponen ragam dan heritabilitas populasi IPB C285 x IPB C290 disajikan pada Tabel 5. Nilai heritabilitas arti luas untuk karakter kuantitatif berkisar antara 0.37-0.80. Karakter yang memiliki nilai heritabilitas arti luas yang termasuk dalam kategori tinggi adalah karakter buah per tanaman, jumlah buah per tanaman, bobot per buah, panjang buah, tebal daging buah, umur berbunga, dan umur panen. Nilai heritabilitas tinggi menunjukkan bahwa karakter tersebut lebih dipengaruhi oleh faktor genetik dibandingkan faktor lingkungan sehingga karakter yang memiliki nilai heritabilitas tinggi menggambarkan bahwa karakter tersebut mudah diwariskan (Widyawati et al., 2014). Hal yang sama juga seperti dilaporkan oleh Lestari et al. (2006) dan Zen (1995) karakter yang memiliki nilai duga heritabilitas tinggi maka seleksi bisa dilakukan pada generasi awal karena karakter dari suatu genotipe mudah diwariskan ke keturunannya, sedangkan jika nilai duga heritabilitas rendah maka seleksi dilakukan pada generasi lanjut.

Beberapa penelitian pada cabai menunjukkan bahwa nilai duga heritabilitas arti luas yang tinggi pada karakter umur berbunga (Lestari et al., 2006), bobot buah per tanaman, jumlah buah per tanaman, panjang buah (Syukur et al., 2010); bobot per buah, panjang buah, diameter buah, tebal daging buah, jumlah buah per tanaman, bobot buah per tanaman, umur panen, dan umur berbunga (Widyawati, 2014); umur berbunga, umur panen (Satriawan et al., 2017); umur berbunga (Hastuti et al., 2016); umur panen (Arif et al., 2012); panjang buah (Dewi et al., 2016); bobot per buah, diameter buah, bobot buah per tanaman, umur panen, jumlah buah per tanaman (Qosim et al., 2013); jumlah buah per tanaman, panjang buah, bobot buah per tanaman (Meena et al., 2016); jumlah buah per tanaman, bobot buah per tanaman, panjang buah dan bobot per buah (Farhad et al., 2008; Chakrabarty dan Islam, 2017). Sementara nilai heritabilitas karakter diameter buah (DB) termasuk dalam kategori sedang. 
Tabel 5. Nilai komponen ragam dan heritabilitas pada karakter komponen hasil cabai populasi IPB C285 x IPB C290

\begin{tabular}{lrrlllllr}
\hline Komponen & \multicolumn{1}{c}{ BBT } & \multicolumn{1}{c}{ JMB } & BB & PB & DB & TDB & \multicolumn{1}{c}{ UB } & \multicolumn{1}{c}{ UP } \\
\hline Ragam P & 14531.53 & 11974.67 & 0.16 & 0.18 & 1.33 & 0.07 & 20.53 & 15.12 \\
Ragam E & 2852.05 & 4142.34 & 0.08 & 0.06 & 0.84 & 0.03 & 5.90 & 6.45 \\
Ragam G & 11679.47 & 7832.33 & 0.08 & 0.12 & 0.49 & 0.04 & 14.63 & 8.67 \\
Ragam aditif & 4512.40 & 6652.50 & 0.07 & 0.06 & 0.48 & 0.04 & 5.26 & 5.07 \\
Ragam non aditif & 7167.07 & 1179.83 & 0.01 & 0.06 & 0.02 & 0.00 & 9.36 & 3.59 \\
Rasio aditif/non & & & & & & & & \\
aditif & 0.63 & 5.64 & 5.68 & 1.15 & 28.50 & 7.79 & 0.56 & 1.41 \\
$h_{b s}^{2}$ & 0.80 & 0.65 & 0.53 & 0.65 & 0.37 & 0.60 & 0.71 & 0.57 \\
$h_{n s}^{2}$ & 0.31 & 0.56 & 0.45 & 0.35 & 0.36 & 0.53 & 0.26 & 0.34 \\
\hline
\end{tabular}

Keterangan: BBT: bobot buah per tanaman; JMB: jumlah buah per tanaman; BB: bobot per buah; PB: panjang buah; DB: diameter buah; TDB: tebal daging buah; UB: umur berbunga; UP: umur panen; $h^{2} b s$ : heritabillitas arti luas; $h_{n s}^{2}$ : heritabillitas arti sempit.

Nilai heritabilitas arti sempit pada populasi IPB C285 x IPB C290 berkisar antara 0.26-0.56. Karakter jumlah buah per tanaman dan tebal daging buah termasuk dalam kategori tinggi. Karakter bobot buah per tanaman, bobot per buah, panjang buah, diameter buah, umur berbunga dan umur panen termasuk kategori sedang. Menurut Syukur et al. (2015) umumnya heritabilitas dalam arti sempit banyak mendapatkan perhatian karena pengaruh aditif dari tiap alelnya diwariskan dari tetua kepada keturunannya.

Karakter yang memiliki nilai rasio ragam aditif lebih tinggi dibandingkan dengan ragam non aditif memiliki nilai heritabilitas arti sempit yang mendekati heritabilitas arti luas seperti pada karakter jumlah buah per tanaman dan tebal daging buah. Hal ini sama seperti yang dilaporkan Arief et al. (2012) bahwa heritabilitas arti sempit yang mendekati heritabilitas arti luas menunjukkan proporsi ragam aditif lebih besar dibandingkan ragam non aditif. Karakter lain yang memiliki rasio ragam aditif yang lebih besar dari ragam non aditif adalah karakter bobot per buah, panjang buah, diameter buah dan umur panen. Hal ini bisa dilihat dari nilai rasionya ragam aditif/non aditif lebih dari 1. Karakter-karakter yang memiliki nilai rasio lebih dari 1 menunjukkan karakter tersebut diduga dikendalikan oleh aksi gen aditif. Karakter yang mempunyai rasio ragam aditif lebih kecil dibandingkan dengan ragam non aditifnya atau nilai rasionya kurang dari 1 yaitu karakter bobot buah per tanaman dan umur berbunga sehingga nilai heritabilitas arti sempitnya jauh lebih rendah dibandingkan dengan heritabilitas arti luas. Berdasarkan nilai heritabilitas arti sempitnya maka metode seleksi yang bisa digunakan pada populasi persilangan IPB C285 x IPB C290 yaitu metode seleksi pedigree yang bisa dilakukan pada generasi awal yaitu pada karakter jumlah buah per tanaman atau bobot per buah. Karakter tebal daging buah tidak direkomendasikan sebagai karakter seleksi walaupun memiliki nilai heritabilitas yang tinggi karena hasil kemajuan seleksi biasanya rendah seperti pada hasil penelitian yang dilaporkan oleh Hastuti (2016). Target dari metode seleksi pedigree yang pada populasi ini diharapkan akan memperoleh kandidat varietas non hibrida yang memiliki jumlah buah per tanaman yang banyak dan memiliki ukuran buah yang lebih besar.

Nilai komponen ragam dan heritabilitas populasi IPB C321 x IPB C290 disajikan pada Tabel 6. Nilai heritabilitas arti luas berkisar antara $0.40-0.81 \%$. Karakter yang memiliki nilai heritabilitas arti luas yang termasuk dalam kategori tinggi adalah bobot buah per tanaman, jumlah buah per tanaman, panjang buah, diameter buah, tebal daging buah, umur berbunga, dan umur panen sementara karakter bobot per buah termasuk dalam kategori sedang. 
Tabel 6. Nilai komponen ragam dan heritabilitas pada karakter komponen hasil cabai populasi IPB C321 x IPB C290

\begin{tabular}{|c|c|c|c|c|c|c|c|c|}
\hline Komponen & BBT & JMB & BB & $\mathrm{PB}$ & DB & TDB & UB & UP \\
\hline Ragam P & 9889.39 & 10738.69 & 0.16 & 0.34 & 1.59 & 0.04 & 21.52 & 23.03 \\
\hline Ragam E & 3024.32 & 2153.05 & 0.10 & 0.08 & 0.80 & 0.02 & 7.41 & 8.97 \\
\hline Ragam G & 6865.07 & 8585.65 & 0.06 & 0.26 & 0.80 & 0.02 & 14.10 & 14.06 \\
\hline Ragam aditif & 3208.86 & 4890.47 & 0.03 & 0.22 & 0.42 & 0.01 & 4.67 & 5.30 \\
\hline $\begin{array}{l}\text { Ragam non aditif } \\
\text { Rasio aditif/non }\end{array}$ & 3656.21 & 3695.18 & 0.04 & 0.04 & 0.38 & 0.01 & 9.44 & 8.76 \\
\hline aditif & 0.88 & 1.32 & 0.67 & 5.03 & 1.11 & 2.24 & 0.49 & 0.60 \\
\hline$h_{b s}^{2}$ & 0.69 & 0.80 & 0.40 & 0.76 & 0.50 & 0.56 & 0.66 & 0.61 \\
\hline$h_{n s}^{2}$ & 0.32 & 0.46 & 0.16 & 0.63 & 0.26 & 0.32 & 0.22 & 0.23 \\
\hline
\end{tabular}

Nilai heritabilitas arti sempit pada populasi IPB C321 x IPB C290 berkisar antara 0.16-0.63. Karakter panjang buah pada populasi ini termasuk dalam kategori tinggi untuk heritabilitas arti sempit. Ruchjaningsih et al. (2000) menyatakan bahwa seleksi terhadap suatu karakter berlangsung efektif jika heritabilitas karakter tersebut tinggi. Hal ini juga didukung dengan nilai rasio ragam aditif dengan ragam non aditif nilainya lebih dari 1 . Karakter lain memiliki nilai rasio ragam aditif lebih tinggi dibandingkan dengan ragam non aditif dengan nilai rasionnya lebih dari 1 adalah jumlah buah per tanaman, diameter buah dan tebal daging buah. Hal ini menunjukkan bahwa aksi gen aditif lebih berperan dibandingkan aksi gen non aditif dalam mengendalikan karakterkarakter tersebut. Karakter bobot buah per tanaman, jumlah buah per tanaman, bobot per buah, diameter buah, tebal daging buah, umur berbunga dan umur panen termasuk kategori sedang $\left(20 \% \leq h_{n s}^{2} \leq 50 \%\right)$, sedangkan karakter bobot per buah termasuk dalam kategori rendah $\left(h^{2}{ }_{n s} \leq 20 \%\right)$. Karakter bobot per buah, bobot buah per tanaman, umur berbunga dan umur panen kemungkinan dikendalikan oleh aksi gen non aditif. Hal ini bisa dilihat dari nilai rasio ragam aditif dengan non aditifnya nilainya dibawah 1. Berdasarkan nilai heritabilitas maka metode seleksi yang bisa digunakan pada populasi persilangan IPB C321 x IPB C290 yaitu metode seleksi pedigree yang bisa dilakukan pada generasi awal yaitu pada karakter panjang buah. Target dari metode seleksi yang dilakukan pada populasi ini diharapkan akan memperoleh kandidat varietas tanaman yang memiliki ukuran buah lebih panjang dibandingkan dengan ukuran tetuanya.

\section{KESIMPULAN}

Nilai heritabilitas arti luas pada populasi IPB C285 x IPB C290 termasuk dalam kategori tinggi untuk semua karakter, kecuali pada karakter diameter buah dan panjang buah. Jumlah buah per tanaman dan tebal daging buah memiliki nilai heritabilitas arti sempit kategori tinggi. Hasil pada populasi IPB C321 x IPB C290 menunjukkan heritabilitas arti luas kategori tinggi untuk semua karakter, kecuali karakter bobot per buah. Karakter panjang buah termasuk dalam kategori tinggi untuk heritabilitas arti sempit. Rasio ragam aditif lebih besar daripada ragam non aditif pada populasi IPB C285 x IPB C290 untuk karakter jumlah buah per tanaman, bobot per buah, diameter buah dan tebal daging buah, sedangkan pada populasi IPB C321 x IPB C290 yaitu karakter jumlah buah per tanaman, panjang buah dan tebal daging buah. Metode seleksi yang bisa digunakan pada kedua populasi ini yaitu metode pedigree sehingga kegiatan seleksi bisa dilakukan pada generasi awal. Populasi IPB C285 x IPB C290 metode seleksi pedigree dilakukan pada karakter jumlah buah per tanaman dan bobot per buah sedangkan pada populasi IPB C321 x IPB C290 metode seleksi pedigree dilakukan pada karakter panjang buah. 


\section{UCAPAN TERIMAKASIH}

Terimakasih penulis sampaikan kepada Kementerian Riset Teknnologi dan Pendidikan Tinggi yang telah membiayai penelitian ini melalui Hibah PUPT atas nama Prof. Dr. Muhamad Syukur, SP. M.Si.

\section{DAFTAR PUSTAKA}

Arif, B.A., S. Sujiprihati, M. Syukur. 2012. Pendugaan parameter genetik pada beberapa karakter kuantitatif pada persilangan antara cabai besar dengan cabai keriting (Capsicum annuиm L.). J. Agron. Indonesia. 40(2): 119-124.

Arif, B.A., L. Oktaviana, S. Sujiprihati, M. Syukur. 2014. Pendugaan parameter genetik karakter umur panen dan bobot per buah pada persilangan cabai besar dan cabai rawit (Capsicum annuиm L.). Bul. Plasma Nutfah. 20(1): 11-18.

Alia, Y., A. Baihaki, N. Hermiati, Y. Yuwariah. 2004. Pola pewarisan karakter jumlah berkas pembuluh kedelai. Zuriat. 15(1): 24-31.

[BPS; DJH] Badan Pusat Statistik dan Direktorat Jenderal Hortikultura. 2018. Produktivitas Sayuran di Indonesia, 2015-2016. Jakarta (ID).

[DPH Kementan] Direktorat Perbenihan Hortikultura Kementerian Pertanian R.I. 2018. Database varietas terdaftar hortikultura. http://varitas.net/dbvarietas/. [20 Februari 2018].

Chakrabarty, S., A.K.M.A. Islam. 2017. Selection criteria for improving yield in chili (Capsicum annuum). Advances in Agriculture. 1-9.

Dewi, A.A., Ainurrasjid, D. Saptadi. 2016. Identifikasi ketahanan tujuh genotip cabai rawit (Capsicum frutescens L.) terhadap Phytophthora capsici (penyebab penyakit busuk batang). J. Produksi Tanaman. 4(3): 174-179.
Ekowahyuni, L.P., M. Syukur, S.H. Sutjahjo, M.R. Suhartanto. 2015. Pendugaan parameter genetik vigor untuk viabilitas dan vigor benih cabai (Capsicum annuит L.) menggunakan analisis setengah dialel. J. Hort. Indonesia. 6(3): 144-151.

Farhad, M., M. Hasanuzzaman, B.J. Biswas, A.K. Azad, M. Arifuzzaman. 2008. Reliability of yield contributing characters for improving yield potential in chilli (Capsicum annuum). Int. J. Sustain. Crop prod. 3(3): 30-38.

Lestari, A.D., W. Dewi, W.A. Qosim, M. Rahardja, N. Rostini, R. Setiamihardja. 2006. Variabilitas genetik dan heritabilitas karakter komponen hasil dan hasil lima belas genotip cabai merah. Zuriat. 17(1): 97-98.

Meena, M.L., N. Kumar, J.K. Meena, T. Rai. 2016. Genetic variability, heritability and genetic advances in chilli, Capsicum annuиm. Biosci. Biotech. Res. Comm. 9(2): 258-262.

Hastuti, N.M.D., I. Yulianah, D. Saptadi. 2016. Heritabilitas dan kemajuan genetik harapan 7 famili populasi F3 hasil persilangan cabai besar (Capsicum аппиит L.) TW 2 X PBC 473. J. Produksi Tanaman. 4(1): 63-72.

Huda, A.N., W.B. Suwarno, A. Maharijaya. 2017. Keragaman genetik karakteristik buah antar 17 genotipe melon (Cucucmis melo L.). J. Hort. Indonesia. 8(1): 1-12.

Qosim, W.A., M. Rachmadi, J.S. Hamdani, I. Nuri. 2013. Penampilan fenotipik, variabilitas, dan heritabilitas 32 genotipe cabai merah berdaya hasil tinggi. J. Agron. Indonesia. 41(2): 140-146.

Ruchjaniningsih, A. Imran, M. Thamrin, M.Z. Kanro. 2000. Penampilan fenotipik dan beberapa parameter genetik 8 kultivar kacang tanah pada lahan sawah. Zuriat. 11(1): 8-14. 
Sujinto, E., M. Dianawati. 2015. Produksi panen berbagai varietas unggul baru cabai rawit (Capsicum frutescens) di lahan kering Kabupaten Garut, Jawa Barat. Pros. Sem. Nas. Masy. Biodiv. Indon. 1: 874-877.

Syukur, M., S. Sujiprihati, R. Yunianti. 2015. Teknik Pemuliaan Tanaman. Bogor (ID) : Penebar Swadaya.

Syukur, M., S. Sujiprihati, A. Siregar. 2010. Pendugaan parameter genetik beberapa karakter agronomi cabal F4 dan evaluasi daya hasilnya menggunakan rancangan perbesaran. J. Agrotropika. 15(1): 9-16.

Satriawan, I.B., A.N. Sugiharto, S. Ashari. 2017. Heritabilitas dan kemajuan genetik tanaman cabai merah (Capsicum аппиит L.) generasi F2. J. Produksi Tanaman. 5(2): 343-348.
Widyawati, W., Y. Izmi, Respatijarti. 2014. Heritabilitas dan kemajuan genetik harapan populasi F2 pada tanaman cabai besar (Capsicum annuum L.). J. Produksi Tanaman. 2(3): 247-252.

Yunandra, M. Syukur, A. Maharijaya. 2017. Seleksi dan kemajuan seleksi karakter komponen hasil pada persilangan cabai keriting dan cabai besar. J. Agron. Indonesia. 45(2): 170-175.

Zen, S. 1995. Heritabilitas, korelasi genotipik dan fenotipik karakter padi gogo. Zuriat. 6(1): 25-32. 